\title{
IMPORTANCE-PERFORMANCE ANALYSIS: REVIEWING THE EVALUATION OF LICENSING SERVICE FOR PRODUCTION CERTIFICATE OF HOME FOOD INDUSTRY
}

\author{
Ariyani Devi Eka*, Setyowati Kristina \\ Faculty of Social and Political Sciences, University of Sebelas Maret, Surakarta, Indonesia \\ Wahyunengseh Rutiana D. \\ Department of Public Administration, University of Sebelas Maret, Indonesia \\ *E-mail: ariyanidevi@student.uns.ac.id
}

\begin{abstract}
The Importance-Performance Analysis (IPA) method is applied in market research to measure the applicant's satisfaction level. This research aims to evaluate and highlight the use of IPA as a management tool in measuring the quality of licensing service for production certificate of home food industry (PIRT). We suggest that this method can be easily implemented in licensing services for home production certificate as work results that include service user input. The research was conducted at the health office through a valid questionnaire: SERVQUAL. This instrument explores the level of service quality perceived by users of licensing service. It was carried out in one area of health resource development; the Ponorogo Health Office in 2016 on food processing licenses which included processed dried fish, dried poultry, coconut, flour, oil and fat, jam or jelly and the similar things, sugar or confectionery and honey, soft drinks or powders, spices, and processed fruit. This research was divided into two stages: first, the beneficiaries answered the questionnaire before using the licensing service and second, the same beneficiaries answered the questionnaire after completing licensing service for food production certificate. Based on the data from the graphs produced by SERVQUAL, it was found that tangible dimension has the highest average in both expectations and perceptions. The responsiveness dimension showed the most negative value among the other dimensions. IPA may be effective for use in licensing home food products because it highlights the key points that must be improved in licensing service for production certificate of home food industry.
\end{abstract}

\section{KEY WORDS}

Service quality, quality indicators, licensing, production certificate, home food industry (PIRT), health service evaluation.

Evaluation of licensing services has become a problem in the current order of government bureaucracy. Up to this day, the assessment method focused on the results of the licensing program (procedure number) and other epidemiological data; regardless of the user's perspective (Gonçalves et al., 2014).

Attention to the expectations and experience of the applicant on this service provides data that is useful for evaluations that should not be ignored. The concept of the ImportancePerformance Analysis (IPA) method lies in the use of community surveys in understanding the importance of applicants' expectations and levels of satisfaction (Gonçalves et al., 2014). Actually, the perceived level of satisfaction sets a two-dimensional matrix of importance and level of performance (Parasuraman et al., 1998). Licensing quality characteristics are divided into four categories according to the level of importance and level of performance so that the government can provide quality services, especially in the field of licensing in accordance with service quality improvement strategies in this category (first priority, maintaining achievement, low priority, and excessive priority). Importance-Performance Analysis (IPA) has been widely used in government administration agencies (Dolinsky, 1991). IPA was first proposed in 1977 as a tool for developing corporate management strategies (Martilla, 1997). 
Since then, IPA framework has gained popularity among researchers in service quality (Ennew, 1993). Research on service quality has been widely conducted, including the service quality in the health sector. (Ibukun Adeosun et al., 2014; Repper, 2014; Chistopher Alan, 2015; Yin-Har Lau \& Ridge, 2011; Brysland \& Curry, 2001).

Thus, the SERVQUAL model is applied to assess the quality of care taking into account client expectations and service perceptions (Ho et al., 2012). This research aims to evaluate the use of IPA as a management tool for licensing services for production certificate of home food industry applied at the Health Office of Ponorogo Regency.

\section{METHODS OF RESEARCH}

Questionnaire design: this research was carried out in the licensing service for production certificate of home industry through the application of questionnaires using the SERVQUAL measurement or assessment method (Parasuraman et al., 1998). This method is based on a comparison between perceived service and expected service, in which the applicant's expectations are influenced by special needs, prior experience, word of mouth communication, and external communication. The difference between perception and expectation value is defined as a service gap. It is very interesting to show that, the lower the gap, the worse the value of the results obtained; i.e. the quality of services that are considered unsatisfactory and need to be improved.

In 2016, there were 108 applicants for licensing production certificate of home industry starting from January 2016 to September 2016. It is presented in the following table:

Table 1 - Number of Applicants for Licensing Production Certificate of Home Industry

\begin{tabular}{|c|c|c|}
\hline No & Months & Number of Applicants \\
\hline 1 & January & 8 applicants \\
\hline 2 & February & 15 applicants \\
\hline 3 & March & 12 applicants \\
\hline 4 & April & 9 applicants \\
\hline 5 & May & 14 applicants \\
\hline 6 & June & 13 applicants \\
\hline 7 & July & 14 applicants \\
\hline 8 & Augustus & 13 applicants \\
\hline 9 & September & 108 applicants \\
\hline
\end{tabular}

Source: Health Office.

Based on the above data, the average number of applicants for licensing production certificate of home industry in one month is 10 applicants. The prevalence of user satisfaction is estimated at $50 \%$. The confidence level is set to $95 \%$, with a $5 \%$ margin of error. Therefore, it is estimated that there are 108 samples of licensing applicants. To measure licensing user satisfaction, the authors used a questionnaire given to licensing applicants containing 20 items formed from the 5 service dimensions as follows:

- reliability: including clarity of requirements and procedures for licensing service;

- responsiveness: related to the alertness of employees to respond to customers;

- assurance: guarantee relating to the quality of processed home industry products;

- tangible: physical characteristics of the service area (including facilities and infrastructure that support the services);

- empathy: non-discriminatory care and treatment in licensing services.

The statement for assessing expectations for the provided services is determined by the following answers/ weights:

- Very Important (VI) weighs 5;

- Important (I) weighs 4;

- Quite Important (QI) weighs 3;

- $\quad$ Not Important (NI) weighs 2;

- Very Not Important (VNI) weighs 1. 
In addition, for the purpose of using the same type of format for assessing the perceptions of the received service, it is determined by the following answers/ weights:

- Very Good (VG) weighs 5;

- $\operatorname{Good}(\mathrm{G})$ weighs 4;

- Fair (F) weighs 3;

- $\operatorname{Bad}(\mathrm{B})$ weighs 2;

- $\quad$ Very Bad (VB) weighs 1.

Service quality itself has 5 indicators - as described in the previous chapter - and is developed into several question items which include:

- Reliability = 5 questions;

- Responsiveness = 4 questions;

- Assurance = 4 questions;

- Empathy = 3 questions;

- $\quad$ Tangible $=4$ questions.

Thus, 5 indicators developed into 20 question items. Based on the analysis, the suitability between expectations and perceptions of services in licensing services are as follows:

- Criteria 1: clarity of requirements for service procedures;

- Criteria 2: employee skills in using computer aids;

- Criteria 3: employee accuracy in providing services;

- Criteria 4: employee ability in responding to questions;

- Criteria 5: employee discipline;

- Criteria 6: employee alertness in providing services;

- Criteria 7: employee ability in answering complaints;

- Criteria 8: employee willingness in providing clear information about the types of licensing certificate for home industry products;

- Criteria 9: employee accuracy in providing services;

- Criteria 10: guarantee on the quality of food products;

- Criteria 11: conformity of product names to industrial owners' names;

- Criteria 12: clarity of information on food additives;

- Criteria 13: security officer;

- Criteria 14: polite and friendly services;

- Criteria 15: neat-looking employees;

- Criteria 16: non-discrimination services

- Criteria 17: availability of supporting means for seating;

- Criteria 18: ease of geographical access;

- Criteria 19: additional facilities e.g. air conditioner and television;

- Criteria 20: parking and prayer room facilities;

- Data analysis.

This research applies quantitative description analysis by assessing respondents on: (1) information about public perceptions on the received services, (2) information about the interests of various types of elements/ indicators of licensing service quality. Information about perceptions and interests is analyzed in two stages which include:

- gap analysis to find out how much the level of gap between customer expectations and perceptions of services they received;

- analysis of Cartesian Diagrams to analyze correlation of data obtained from the first analysis with the aim of determining how closely the correlation between each dimension of service quality perceived by the community. The Cartesian Diagram matrix is used to describe the correlation of closeness.

This matrix is a chart divided into four parts which are limited by two lines intersecting perpendicular to the points (X, Y) as defined by Umar (2002):

"The Cartesian diagram is a space consisting of 4 parts which are limited by two lines that intersect perpendicular to the points $X$ and $Y$. Point $X$ is the average score of the level of 
perception of the service implementation/ performance while point $Y$ is the average score level of importance/ expectation.
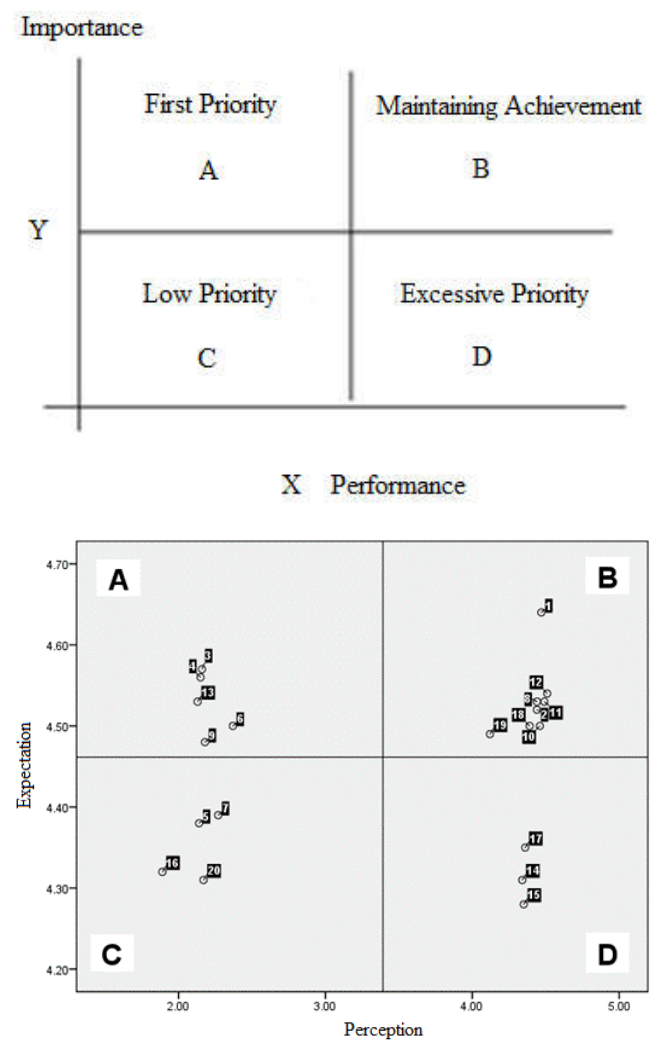

Note: $Y=$ Expectation of the service; $X=$ Perception of the service.

Figure 1 - Service Quality in the Cartesius Diagram

The perception and expectation values for the services are measured based on 5 dimensions of service quality. The measurement results each have aspects of service on the determinants of service quality which include: immediately repaired, maintained, not maintained, or has been over-implemented.

Based on the results of the assessment, it will produce a calculation regarding the level of conformity between customer perceptions and expectations of the licensing service quality in production certificate of home food industry at Ponorogo Regency. The degree of conformity is the result of a comparison of perceived experiences and expectations. This level of conformity will determine the order of priority for improvement or in improving service quality. The level of conformity of these aspects of service will be elaborated and divided into 4 parts in the Cartesian Diagram (Nasution, 2001).

\section{RESULTS OF STUDY}

Based on the findings obtained from the gap of 5 licensing service quality, it shows that line $X$ shows the perception value of the reality of service while line $Y$ shows the customer expectation value for the service.

The quality of licensing services for production certificate of home food industry (IRT) in the health service is good. It can be seen from the most indicators in the B quadrant; i.e. the tangible dimension which has the highest average in both expectations and perceptions. Meanwhile, services that must be improved are: responsiveness dimensions that show the most negative values related to employee accuracy, employee ability in responding to questions, employee alertness, and employee accuracy. 
Based on the above picture, it can also be concluded that there are gaps in the quality of licensing services between what the applicants receive and expect for licensing service for production certificate of home food industry. It has been proven that there are several indicators/ items in quadrant $A$ which should be a top priority and are considered important for the community. However, the service provider has not provided it according to customer expectations. Based on the results of data analysis, the value of $X=3.41$ and the average $Y$ $=4.44$. Thus, it is concluded that perceptions/ performances are lower than expectations.

\section{DISCUSSION OF RESULTS}

The research findings propose that IPA can be an important tool for identifying strengths and weaknesses in evaluating services in the licensing sector. The matrix with four quadrants helps establish and determine a plan to improve service quality as measured by the expectations and perceptions of service users. This research found that the greatest concentration needs are in the tangible and empathy dimensions.

Table 2 - Means of Perceptions and Expectations of SERVQUAL

\begin{tabular}{|c|c|c|c|c|}
\hline Items & $\begin{array}{l}\text { Perception } \\
\text { Levels (X) }\end{array}$ & $\begin{array}{l}\text { Expectation } \\
\text { Level }(Y)\end{array}$ & $\begin{array}{l}\text { Average Value of } \\
\text { Perception (X) }\end{array}$ & $\begin{array}{l}\text { Average Value of } \\
\text { Expectation }(Y)\end{array}$ \\
\hline Clarity of requirements for service procedures & 447 & 464 & 4.47 & 4.64 \\
\hline Employee skills in using computer aids & 444 & 452 & 4.44 & 4.52 \\
\hline Employee accuracy in providing services & 216 & 457 & 2.16 & 4.57 \\
\hline Employee ability in responding to questions & 215 & 456 & 2.15 & 4.56 \\
\hline Employee discipline & 214 & 438 & 2.14 & 4.38 \\
\hline \multicolumn{3}{|c|}{ Average of Tangible } & 3.07 & 4.53 \\
\hline Employee alertness in providing services & 237 & 450 & 2.37 & 4.5 \\
\hline Employee ability in answering complaints & 227 & 439 & 2.27 & 4.39 \\
\hline Employee willingness in providing clear & & & & \\
\hline $\begin{array}{l}\text { information about the types of licensing } \\
\text { certificate for home industry products }\end{array}$ & 444 & 453 & 4.44 & 4.53 \\
\hline Employee accuracy in providing services & 218 & 448 & 2.18 & 4.48 \\
\hline \multicolumn{3}{|c|}{ Average of Responsiveness } & 2.81 & 4.47 \\
\hline Guarantee on the quality of food products & 446 & 450 & 4.46 & 4.5 \\
\hline $\begin{array}{l}\text { Conformity of product names to industrial } \\
\text { owners' names }\end{array}$ & 449 & 453 & 4.49 & 4.53 \\
\hline Clarity of information on food additives & 451 & 454 & 4.51 & 4.54 \\
\hline Security officer & 213 & 453 & 2.13 & 4.53 \\
\hline \multicolumn{3}{|c|}{ Average of Assurance } & 3.89 & 4.52 \\
\hline Polite and friendly services & 434 & 431 & 4.34 & 4.31 \\
\hline Neat-looking employees & 435 & 428 & 4.35 & 4.28 \\
\hline Non-discrimination services & 189 & 432 & 1.89 & 4.32 \\
\hline \multicolumn{3}{|c|}{ Average of Empathy } & 3.52 & 4.30 \\
\hline Availability of supporting means for seating & 436 & 435 & 4.36 & 4.35 \\
\hline \multirow{3}{*}{$\begin{array}{l}\text { Ease of geographical access } \\
\text { Additional facilities e.g. air conditioner and } \\
\text { television } \\
\text { Parking and prayer room facilities }\end{array}$} & 439 & 450 & 4.39 & 4.5 \\
\hline & 412 & 449 & 4.12 & 4.49 \\
\hline & 217 & 431 & 2.17 & 4.31 \\
\hline \multicolumn{3}{|c|}{ Average of Physical Evidence } & 3.76 & 4.41 \\
\hline \multicolumn{3}{|c|}{ Average of All Values } & 3.41 & 4.44 \\
\hline
\end{tabular}

Paying attention to the above results of the Cartesian quadrant, quadrant $A$ (Top Priority) has 5 Criteria/ attributes that are the top priority that must be improved. It is because the level of licensing satisfaction is less than the expectations of employees in the health sector of the licensing sector. It includes the employee accuracy in providing services and responding to questions that are still considered to be less by the applicant who will apply the production certification of home food industry. Responding to the question, in this case is the role of licensing officers in serving the licensing for all household industrial products in Ponorogo Regency including food and beverage processing industries with a geographical location within the radius of up to $60 \mathrm{~km}$. In addition, it has a variety of regional characteristics which of course has very diverse types of society; from urban to rural areas. In this case, they are mostly rural people who think that the service of responding to the questions they ask is unsatisfactory because basically the officers explain what is the existing in the Standard Procedure for Services. Meanwhile, the applicants need a quick and 
practical step that can immediately realize the licensing for making home food industry certificates. However, the applicants are required to participate in a food extension certificate activity which can be carried out if the quota meets the standards of 30 applicants.

$B$ quadrant (maintaining the achievement) has 8 criterial attributes whose achievements need to be maintained. Customers expect these factors and they assume that they are in accordance with their expectations so that the level of satisfaction is relatively higher. It is better to have clarity of service requirements and procedures, employee skills in using computer aids, employee willingness in providing clarity of information regarding types of licensing services, and additional facilities e.g. air conditioner and television continue to be maintained. Basically, all service operating standards for service users are available to support the smooth functioning of officers in providing maximum service to users. The services and facilities provided aim to provide a sense of security, comfort to service users so that they feel satisfied in using licensing services for production certificate of home food industry (PIRT).

Quadrant C (attributes to maintain) only has 5 criteria. It is a low priority attribute meaning that it is not necessary to prioritize this attribute because it is indeed not expected by the users. It should be reconsidered for the increase because in reality the implementation of the attributes is not too special and is considered less important by consumers so that the benefits received are also relatively small. In terms of employee discipline, in the Health Resources Development (PSDK) in Ponorogo Regency, employees carry out their duties in full discipline, responsibility, professional and capable of answering customer complaints and not discriminating against all licensing applicants. All applicants are served without distinguishing ethnicity, race and religion. All are considered equal and have the right to receive the same services supported by professionalism of officers and room comfort facilities so that customers feel satisfied. In addition, the limited parking area is also able to be fully utilized by the service applicants in conducting licensing services in Ponorogo Regency. Although this is not very important, it remains a supporting factor to give convenience for the people requesting services at the Health Office of Ponorogo Regency.

Quadrant D (main to priority) has 3 criteria. The criteria/ attributes in quadrant D are surplus attributes. It means the performance is very good but it is not an expected (not important) attribute for the user. It is preferably to reduce the increase in this attribute so that it can save costs. It includes: polite and friendly services, neat-looking employees, and the availability of comfortable and non-boring seating support facilities which makes the applicants of licensing services unsaturated and continue to carry out the services comfortably.

Based on the results of the above Cartesian diagram analysis, the most criteria are in Quadrant B, i.e. 8 criteria. It means that the criteria/ attributes of service quality in quadrant B are factors that are considered important by the customer and in accordance with what they feel so that the level of satisfaction is relatively higher. In other words, the customer's performance and expectation are high-level variable and are appropriate. Thus, the company or organization is sufficient to maintain variable performance so that the services provided to applicants are satisfactory services.

\section{CONCLUSION}

Based on the theory and the findings that have been verified, the service quality in each service provider agency is largely determined by customer assessment. Knowing customer assessment of service quality can be conducted using Service Quality Theory as stated by Parasuraman \& Berry (1990). It is carried out using gap 5; i.e. service quality which is measured by the level of gap between customer expectations and perceptions. In these measurements there are 20 dimensions/ variables and simplified into 5 dimensions including Reliability, Responsiveness, Assurance, Tangible, and Empathy. Determination of the 5 dimensions above is based on the relevance and compatibility with the characteristics of the assessment of services available at the Health Service of Ponorogo Regency. 
The research findings are expected to be used as a reference for the development of the Public Administration practice, specifically related to Public Service Management. Further research needs to conduct research relating to licensing services in inclusive perspectives.

\section{REFERENCES}

1. Brysland, A. \& Curry, A. (2001). Service Improvement in Public Services Using SERVQUAL. Managing Service Quality. 11, 389-401.

2. Dolinsky, A.L. and Caputo, R.K. (1991) Adding a competitive dimension to importanceperformance analysis: An application to traditional health care systems. Health Marketing Quarterly, 8, 61-79. http://dx.doi.org/10.1300/J026v08n03_03

3. Ennew, C.T., Reed, G.V. and Binks, M.R. (1993) Importance-performance analysis and the measurement of service quality. European Journal of Marketing, 27, 59-70. http://dx.doi.org/10.1108/03090569310026402

4. Gonçalves, J. R., Pinto, A., Batista, M. J., Pereira, A. C., \& Ambrosano, G. M. B. (2014). Importance-performance analysis: Revisiting a tool for the evaluation of clinical services. Health, 6(05), 285. DOI:10.4236/health.2014.65041

5. Ho, L. H., Feng, S. Y., Lee, Y. C., \& Yen, T. M. (2012). Using modified IPA to evaluate supplier's performance: Multiple regression analysis and DEMATEL approach. Expert Systems with Applications, 39(8), 7102-7109.

6. Ibukun Adeosun, I., Adekeji Adegbohun, A., Oyewunmi Jeje, O., \& Adejoke Adewumi, T. (2014). Experiences of discrimination by people with schizophrenia in Lagos, Nigeria. Journal of Public Mental Health, 13(4), 189-196.

7. Martilla, J. \& James, J. (1977) Importance-performance analysis. Journal of Marketing, 41, 77-79. http://dx.doi.org/10.2307/1250495

8. Nasution. (2001). Manajemen Mutu Terpadu (Total Quality Management), Anggota IKPI, Ghalia Indonesia: Jakarta.

9. Parasuraman, A., Zeithaml, V. and Berry, L. (1998) SERVQUAL: A multiple-item scale for measuring consumer perceptions of service quality. Journal of Retailing, 64, 12-40.

10. Repper, R. P. A. J. (2014). Challenging discrimination within mental health services: The importance of using lived experience in the work place. Mental Health and Social Inclusion, 18(3).

11. Umar, H. (2002), "Metodologi Penelitian”, Untuk Skripsi dan Tesis Bisnis, Jakarta: PT. Raja Grafindo Persada.

12. Yin-Har Lau, A., \& Ridge, M. (2011). Addressing the impact of social exclusion on mental health in Gypsy, Roma, and Traveller communities. Mental Health and Social Inclusion, 15(3), 129-137. 